Article

\title{
Efficiency Impact of the Communal Land Distribution Program in Northern Ethiopia
}

\author{
Shunji Oniki ${ }^{1, *}$, Melaku Berhe ${ }^{2}$ and Koichi Takenaka ${ }^{3}$ \\ 1 Social Sciences Division, Japan International Research Center for Agricultural Sciences (JIRCAS), Tsukuba, \\ Ibaraki 305-8686, Japan \\ 2 Department of Agricultural and Resource Economics, College of Dryland Agriculture and Natural \\ Resources, Mekelle University, P.O. Box 231, Mekelle, Tigray Region, Ethiopia; melaku.berhe@mu.edu.et \\ 3 Rural Development Division, Japan International Research Center for Agricultural Sciences (JIRCAS), \\ Tsukuba, Ibaraki 305-8686, Japan; koichitk@affrc.go.jp \\ * Correspondence: oniki.shunji@affrc.go.jp; Tel.: +81-29-838-6382
}

Received: 18 April 2020; Accepted: 26 May 2020; Published: 29 May 2020

\begin{abstract}
A rapid increase in population in sub-Saharan Africa has caused a decrease in farm size, an increase in the number of landless farmers, and soil erosion in communal forests due to increasing utilization. Ethiopia has addressed this problem by introducing an epoch-making privatization policy for the allocation of communal land to landless farmers. This policy promotes the economic utilization of the communal land while protecting natural resources. Hitherto, few studies have evaluated the impact of the policy. We evaluate the effect of the communal land distribution policy for tree-planting using technical efficiency of farm production by estimating a stochastic production function model in the Tigray region of Ethiopia. We compare the technical efficiencies of farm production between both participating and nonparticipating farms in the program using a quasi-experimental method. The results reveal the improvement of technical efficiency through communal land distribution. Therefore, program activities could increase farm incomes while maintaining land conservation. Thus, the allocation of communal land promotes sustainable land utilization in the mountainous areas of sub-Saharan Africa.
\end{abstract}

Keywords: soil and water conservation; land allocation; tree planting; East Africa

\section{Introduction}

Many developing countries with communal hillside areas face challenges concerning soil erosion and land degradation. Consequently, this results in the reduction of farmland productivity and farmers' incomes. To mitigate these challenges, land conservation and the rehabilitation of vegetation have commenced by the introduction of enclosures and free-grazing restrictions. However, most areas do not offer sufficient off-farm employment opportunities, leading to a decrease in the income per capita as the rural population increases. Therefore, the government is effectively utilizing the communal lands, which were previously conserved.

In Ethiopia, a great deal of communal land is not fully utilized economically [1]. A limited number of farm animals are allowed to enter communal lands to prevent land degradation [2]. Commercial forestry production by individual farmers, instead of commercial farms, is also limited. If communal land could be utilized more efficiently, the income of farming households could increase.

In the northern areas of Ethiopia, the opportunity for non-farm employment is limited. Especially in mountainous areas, there are few irrigated lands, and, therefore, labor is abundant during the dry season when farming is suspended. To utilize communal lands and surplus labor more effectively, the Tigray Region in Ethiopia introduced the Hillside and Gully Distribution Program for landless farmers 
in 2011 (Tigray Bureau of Agriculture and Rural Development, "Directives on Area Closure (Hillside and Gully) Development and Utilization", January 2011, Mekelle, Tigray Region; it was introduced in some districts in 2009 and fully introduced in 2011.). The government allocates communal lands to farmers who do not own registered farmlands. This enables farmers to perform conservation activities to generate income off the land, like planting eucalyptus trees. This program is being expanded to other regions in Ethiopia and is being considered in other areas in sub-Saharan Africa with similar social and natural conditions.

Various studies indicate that land distribution programs in developing countries result in the improved efficiency of local economies [3-7]. However, most studies focus on the impact of the redistribution policies of existing farmlands. Few policies have been analyzed communal land distribution programs.

Particularly, we are unsure whether a distribution program for communal forests increases the efficiency of farm production. Tree planting occurs at the beginning of the rainy season, which overlaps with the crop-planting period. If the time spent on conservation or tree planting interferes with farming, household incomes may not increase. If farmers efficiently utilize surplus labor, they could increase household incomes through tree planting. Thus, an empirical question posed here is whether household incomes increase.

The purpose of this study is to test efficiency improvement effects of a communal land distribution program in the Tigray Region of Ethiopia by comparing the technical efficiencies of those who did and did not participate in the program. The measurement of technical efficiencies for forestry or agroforestry has been applied in many studies [8-13]. Few studies have measured efficiency changes by policy programs to provide communal land for tree planting. Whether communal land distribution increases technical efficiency depends on the efficient use of abundant labor, as the availability of capital investment is limited in a developing country. In this study, we investigate whether technical efficiency improves through communal land distribution to landless farmers who have abundant time for additional work.

One of the important conditions for the land distribution program is the availability of a sufficient labor force in rural areas. In the case of a labor shortage, farmers are unable to increase their incomes adequately, even though they obtain additional lands. We could suppose that due to a rapid increase in the rural population in sub-Saharan Africa, labor surplus exists in rural areas, especially during off-seasons for farming [14]. Surplus agricultural labor can be allocated to non-agricultural employment opportunities, hence diversifying the income streams [15-18]. Contrarily, labor shortage and off-farm incomes in rural areas do not increase beyond a limit [19-24].

Several studies have estimated the impact of the land tenure system on natural resource management in comparison to the land property rights systems in different areas [25-29]. Although these studies control the geographical or social differences between study sites, controlling all characteristics of sites is difficult, and missing variables may exist. It is preferable to compare a randomly selected sample for two tenure systems. However, such an experiment is difficult to implement.

\section{Communal Land Distribution Program in Ethiopia}

In the Tigray Region of Ethiopia, most forests and other communal lands were highly degraded before the 1990s due to human-induced factors like firewood collection by locals, animal grazing, and political instability [30,31]. Since the downfall of the socialist regime, local governments protect the communal lands. They implemented village bylaws for communal land management, which has contributed to the conservation of natural forests [30,32].

Due to the rapid increase in Ethiopia's rural population, the number of landless young farmers has increased. After the socialist regime led by the military government ended in Ethiopia, land-use rights were awarded to individuals, while the government retained ownership of all land. The selling or mortgaging of land was prohibited [33]. The Federal Land Proclamation was implemented in 1997. 
It was followed by new regional land laws in 1998 in Tigray, through which the official registration of farmlands was implemented [33]. New farmlands were generally not allocated to younger farmers during the land registration process due to the lack of additional land in rural areas. As a result, many landless farmers emerged after the registration. Therefore, the majority of Ethiopian youth in rural areas are landless farmers [34]. These individuals are only able to farm by renting land or sharecropping, an unfavorable economic situation.

The hillside distribution program was introduced in 1999 in certain districts in the Tigray Region to improve the condition of young landless farmers. The regional government expanded the program to all local areas by 2011. The Amhara region in Ethiopia initiated a similar program [35]. Allocated lands are communal lands administrated by local communities, such as villages (tabia), sub-villages (kushet), and settlements (gote) in the Tigray Region [36]. Most communal lands were devolved to the local communities.

According to program regulations, allocated land must be used for conservation activities that generate income, such as tree planting, agroforestry, fodder collection for livestock, and apiculture. Activities conducted on allocated land are designed and monitored by experts from the natural resource departments of district (woreda) offices to ensure that no further soil erosion occurs. Land use can only be transferred to children or grandchildren who do not own land. Furthermore, land can also be rented to other individuals on the condition that they utilize the land sustainably. The standard distribution per person is 0.5 hectares for hillside areas or 0.25 hectares for riverside (gully rehabilitation) areas.

The communal land distribution program in Ethiopia mirrors the characteristics of semi-private lands. While those who receive allocated communal lands can obtain earnings from land activities, they must engage in activities determined by the village. These activities must contribute to the conservation of areas. Famers who fail to adhere to the designated rules of utilization or do not use the land must return it to the village. Thus, people do not have the decision-making authority regarding the utilization of allocated lands. Additionally, they cannot sell or rent allocated lands to other individuals.

Semi-private land systems are also prevalent in other countries [37,38]. These include not only socialist countries, but also capitalist countries with land institutions relating to private and communal ownership. In developing countries, many customary land institutions are not fully private or public. However, a government policy of the semi-privatization of communal lands for landless farmers is uncommon. The impact of the evaluation of such a policy has rarely been conducted in the past.

\section{Theoretical Framework}

The dual-sector model of Lewis [39] explains that the development of a rural area with abundant labor requires the development of the non-agricultural sector. The shortage of labor in rural areas caused by the development of the non-agricultural sector increases agricultural wages. However, excessive labor or disguised unemployment [40] can exist in rural areas with large populations. While labor availability varies across countries in sub-Saharan Africa, non-farm employment opportunities in rural areas are important for a country's economic development [15].

Non-farm income in urban areas is the driving force for increasing rural incomes in developing countries. Often, increasing the output per capita in agriculture is challenging due to high population growth rates in rural areas. Non-farm employment in rural and urban areas is essential to increase household income and to reduce wealth inequality [41-48]. An underdeveloped country with a large population, such as Ethiopia, has limited non-farm employment opportunities in urban areas due to the under-development of industrial sectors; therefore, non-farm employment opportunities should also be extended to rural areas.

Ethiopia has large areas of communal land where economic activities are limited. Contrarily, farmers' non-farming activities, such as small-scale forestry, could be profitable [49-51]. Farmers increasing their income depends on whether they can utilize surplus labor effectively. In Ethiopia, non-farming activities, such as trading, handicrafts, sale of local food and beverages, and mining, are 
absent in areas removed from main roads [52]. Thus, surplus labor exists in rural areas of the Tigray Region in Ethiopia [1].

The hypothesis in this study states that due to the surplus labor in rural areas, participation in the program increases farm household incomes. Specifically, program activity work does not reduce the efficiency of agricultural production or other non-farm activities. This is not evident because of possible labor shortages in rural areas in Africa.

\section{Data}

The data used in this study were obtained through original surveys conducted in August 2014 in three villages (tabias) of the Emba Alaje District (woreda) in the Southern Zone of the Tigray Region in Ethiopia (Figure 1). The district is situated approximately $670 \mathrm{~km}$ north of Addis Ababa, the national capital, and approximately $100 \mathrm{~km}$ south of Mekele, the Tigray Region's capital. The surveyed villages, namely Keyih Tekli, Egri Albe, and Abeda, are mountainous areas located in the central part of the district. The altitude of the district center is $2465 \mathrm{~m}$, and that of the villages ranges from 2300 to 3000 $\mathrm{m}$ above mean sea level. The soil in Emba Alaje is mostly Lithic Leptosols, which is the typical soil in Ethiopia [53]. This area is characterized as a highland where the temperature is relatively low. The average annual precipitation during 1998-2009 was $636 \mathrm{~mm}$. The average high and low temperatures during 1992-2013 in the nearest city, Maychew, were 22.2 and $10.3^{\circ} \mathrm{C}$, respectively (precipitation and temperature data were directly obtained from the National Meteorological Agency of Ethiopia; data of temperatures in Adishehu are not available; Maychew is $37 \mathrm{~km}$ south of Emba Alaje, and the altitude at Maychew is $2479 \mathrm{~m}$ ). This climate is suitable for Eucalyptus tree planting. Thus, Eucalyptus is the dominant tree species for timber production in the Tigray highlands [54] Particularly, in Emba Alaje District, Eucalyptus globulus and Eucalyptus camaldulensis are used for plantation $[55,56]$. No other trees are planted for timber production in the district.

The population density in the district is 140.6 per $\mathrm{km}^{2}$, which is higher than that of the whole of Ethiopia (73.9 per $\mathrm{km}^{2}$ ) [57]. In the area under study, very few people migrate to urban areas in search of non-farm and local non-agricultural employment opportunities, which are limited to carpentry and wage work for agriculture in villages. Therefore, there is a labor surplus among landless farmers, particularly during the dry season. Therefore, there may be excessive labor or disguised unemployment in this area.

Natural and social conditions vary in such areas as the Tigray Region. Therefore, the demand for the hillside distribution program also differs in these areas [58]. Participation rates for the program in the midland (i.e., 1500-2300 $\mathrm{m}$ above sea level) are lower than those in the highland [59,60].

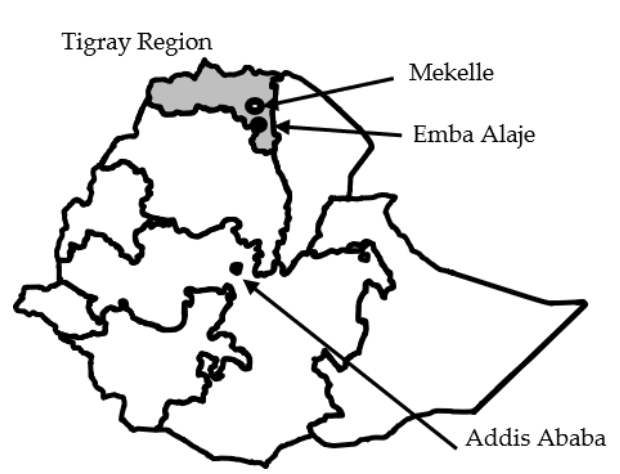

(a) Ethiopia

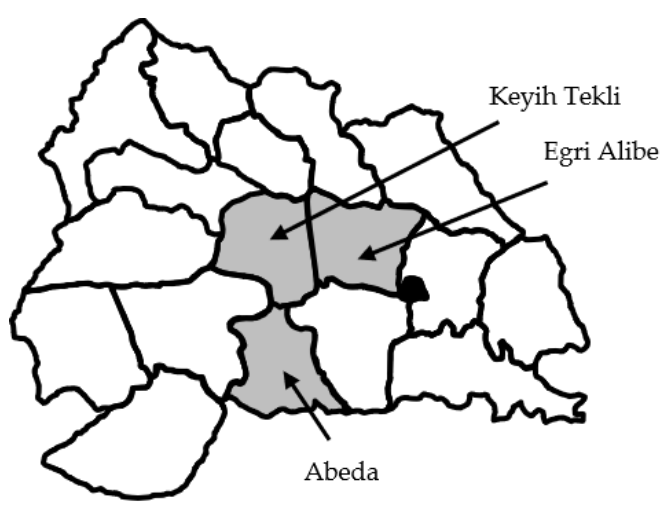

(b) Emba Alaje District

Figure 1. Study areas.

Since the total distributed land is limited, only a fraction of the applicants are approved. Thus, the area allocated in our study site (Emba Alaje) is smaller than other areas in the Tigray Region. In 
the study site, participants were granted 0.25 hectares for hillside renovation and 0.125 hectares for gully rehabilitation.

The quasi-experiment to understand the effects of participation on the hillside distribution program was implemented in three villages. Although our study did not separate a target group for participants and a control group for non-participants before the program commenced, the local government randomly selected participants from eligible individuals. Certain villages in the Tigray Region had fewer applicants than the number of plots offered; all applicants were allocated lands. Villages in the Emba Alaje District had more applicants than available plots. The district office applied a lottery system to select participants. Thus, participants and non-participants can be compared without considering endogeneity in the selection process.

First, we drafted a list of all participants and non-participants in the program who were landless farmers in each village. Next, we selected 60 participants and 60 non-participants from each list using a random sampling method. We compared these two samples and tested whether there were any differences between the groups.

As defined by the government, landless farmers are those who do not own farmlands registered in their names. Note that farmlands are not allocated to households, but individuals; therefore, some landless farmers could have a spouse who owns farmlands. We excluded such households from our sample.

Since many trees planted as part of the program had not grown sufficiently for harvesting, we estimated future expected forestry income for young trees using data of other households growing Eucalyptus trees. We conducted another survey of the households in 2014. We randomly selected 64 households from two sub-villages ( $k$ ushet: Telema and Minchere) in the Keyih Tekli tabia; 52 households among them had planted trees five years earlier. The results of the survey are presented in Table 1. The number of observations is inconsistent, as respondents were unsure of specific questions. The approximate income per tree was calculated by subtracting all operating costs from the revenue-the estimated net income for the forest per survived tree was 5.83 Birr per year. The estimated income per hectare of planted land was calculated by multiplying the expected income per tree and the number of seedlings per hectare. We assume that farmers adhered to district office guidelines, which recommended 2500 planted seedlings per hectare. Some farmers planted more than the recommended number; however, dense planting does not necessarily increase profits per area due to the decrease in tree growth.

Table 1. The situation of tree planting in homesteads and farmlands.

\begin{tabular}{cccc}
\hline & $\begin{array}{c}\text { Number of Trees } \\
\text { Survived }\end{array}$ & $\begin{array}{c}\text { Average Period after } \\
\text { Planting (Year) }\end{array}$ & $\begin{array}{c}\text { Annual Net Income Per } \\
\text { Tree (Birr) }\end{array}$ \\
\hline Mean & 177 & 8.3 & 5.83 \\
Maximum & 1000 & 41.0 & 15.94 \\
Minimum & 25 & 3.0 & 0.41 \\
Standard deviation & 161 & 5.7 & 3.41 \\
Number of observations & 61 & 62 & 60 \\
\hline
\end{tabular}

Source: The household survey in Emba Alaje District for this study.

By using an estimated forestry income, we computed the average annual income per laborer (Figure 2). The total income and the income per activity for participants and non-participants in the program were compared. We did not find any significant differences between participants and non-participants in agricultural and livestock income. The non-farm incomes of the participants were lower than those of the non-participants. Regarding forestry income, participants earned more than non-participants, most of which were derived from tree planting in distributed land. The total income of participants was higher than that of non-participants. 


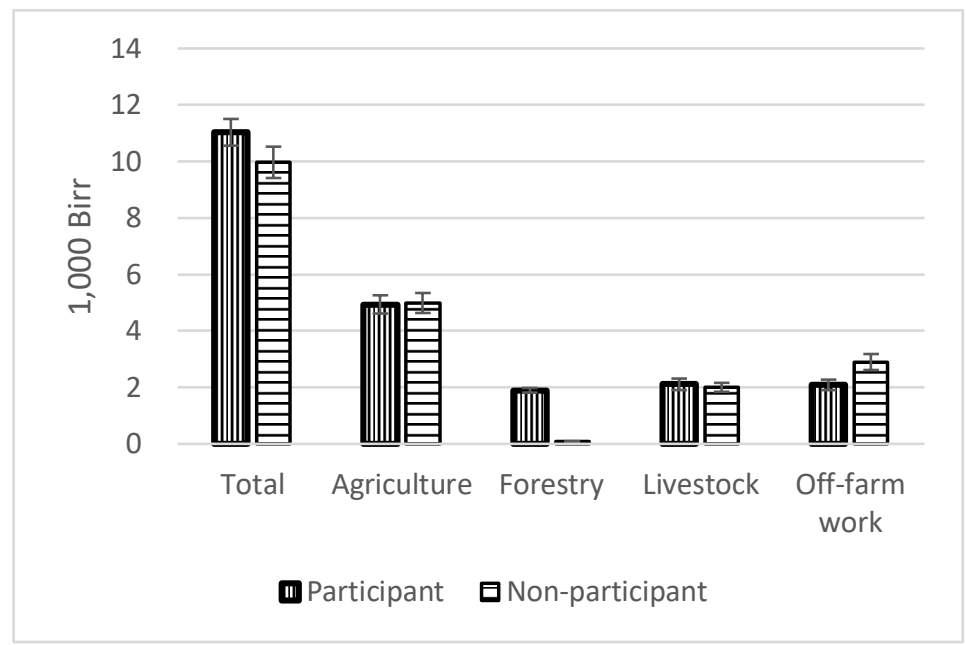

Figure 2. Average annual net income per person by activity.

\section{Method}

To examine whether the program improved the efficiency of farming, we estimated the technical efficiency using a stochastic frontier production function model. The technical efficiency is the proportion of the output level relative to the technical frontier, which is the maximum level of potential output under a specified level of labor and land. This method can measure technical improvement triggered by public policy. Regarding the land distribution program, we can illustrate whether the program induced efficient utilization of production factors, such as family labor. The advantage of the stochastic frontier model is that it allows for potential errors when estimating the production frontier. It has been applied in several economic studies in Africa (e.g., Ahmed et al. [61]); however, few studies have tested actual rural policy programs using the model.

The stochastic frontier model is expressed as

$$
\ln y=\alpha+\sum_{i} \beta_{i} x_{i}+\sum_{i} \sum_{j} \beta_{i j} x_{i} x_{j}+\sum_{i} \beta_{i i} x_{i i}^{2}-u+\varepsilon
$$

where $y$ denotes the household income, $x_{i}$ denotes factors of production, i.e., the log of the number of laborers (labor), the log of the farmland area for the household (farm), the area of tree planting for the household (forest), and the total number of livestock in the tropical livestock unit (animal), $u$ denotes the inefficiency term with half normal distribution, and $\varepsilon$ denotes the error term of the frontier model. We assume that the factors of production are exogenous because the factors cannot be altered in the short run in rural Ethiopia.

The inefficiency model is as follows:

$$
u=\delta_{0}+\gamma p+\sum_{i} \delta_{i} z_{i}+\eta
$$

where $p$ denotes the dummy variable for program participation, $z_{i}$ denotes the variable for household characteristics, and $\eta$ denotes the error term. The Equations (1) and (2) are estimated by the maximum likelihood method [62].

Total income refers to the sum of agricultural, forestry, livestock, and non-farm incomes. Forestry income references estimated incomes from tree planting, as discussed earlier. Non-farm income includes earnings from non-farm employment and the aid program (the Productive Safety Net Program, initiated in 2005 in response to the food shortage in Ethiopia). Livestock income considers all animal-related income, including the farmers' consumption of production.

The farmland areas used for crop cultivation are rented or sharecropped and, in several cases, belong to the farmer's parents. Tree-planting areas include areas in homesteads and around farmlands, 
as well as communal land distributed in the program. Labor is defined as farmers aged above 18 years. A farmworker aged between 6 and 17 is counted as half a person.

The household characteristic variable age20_29 is the dummy variable for the household head who is 20 to 29 years old, and the variable age30above refers to a person who is 30 years old and above. The household head's education is characterized by $e d u c_{-} 0$, the dummy variable for heads without school education, educ1_4 for heads with one to four years of education, and educ5_9 for heads with five to nine years of education. The variable female represents a female-headed household. The variable distance indicates the distance in $\mathrm{km}$ from a house to the main road on which buses drive to the district's center. We also use dummy variables for villages: village_A for Abeda and village_E for Egri Alibe.

Descriptive statistics are listed in Table 2. A significant disparity exists among landless farmers concerning income, number of laborers, cultivated area, sharecropping ratios, and the number of livestock per household. Most landless farmers are young, and the average age is 31.8 years. The number of female-headed households is low, as most of them are young. The average number of years of education for the household head is 3.9 years, while it ranges from 0 to 12 years.

Table 2. Descriptive statistics of households in the Landless Farmers Survey, 2014.

\begin{tabular}{|c|c|c|c|c|c|}
\hline Variable & Unit & Mean & Standard Deviation & Minimum & Maximum \\
\hline Annual income & birr & 10,500 & 4014 & 3225 & 20,100 \\
\hline Number of laborers & number & 2.217 & 0.329 & 1.500 & 3.500 \\
\hline Cultivated land & hectare & 0.440 & 0.233 & 0.100 & 1.750 \\
\hline Tree planting land & hectare & 0.248 & 0.221 & 0.004 & 1.454 \\
\hline Number of animals & TLU & 35.9 & 14.3 & 0.5 & 80.5 \\
\hline Household head age & & 31.8 & 5.9 & 19.0 & 50.0 \\
\hline Years of education of the head & & 3.9 & 3.4 & 0.0 & 12.0 \\
\hline Female-headed household & proportion & 0.042 & 0.201 & 0.000 & 1.000 \\
\hline Distance & & 1.089 & 1.527 & 0.010 & 10.000 \\
\hline Sharecropping ratio & & 0.590 & 0.469 & 0.000 & 1.000 \\
\hline
\end{tabular}

\section{Results}

Table 3 illustrates the results of the estimation of the frontier function for the total income per household. The statistic of $\sigma^{2}$ is the variance of the inefficiency term, $u$, being significantly greater than zero, which suggests the existence of the inefficiency effect in Equation (2). In addition, $\gamma$ is the ratio of $\sigma^{2}$ to the total errors in Equation (1), indicating that the errors in the frontier function are explained by the inefficiency model. The log likelihood test for the null hypothesis of $\gamma=0$ is rejected at the $1 \%$ level. These statistics support our representation of the efficiency model.

As per the estimates of the efficiency model shown in Table 3, the coefficient of participation is negative and significant at the $1 \%$ level. This shows that the hillside distribution program increases the technical efficiency regarding labor when other factors are controlled similarly. This supports our hypothesis that excess labor is used more efficiently if the farmer participates in the program.

Table 4 displays the coefficient estimates of the stochastic production function model for agricultural income, including income from livestock. The coefficient for participation is not significant; therefore, participation in the program does not affect the efficiency of agricultural production. This implies that the work time for program activities does not conflict with farming activities. Table 5 presents estimates for non-agricultural incomes, such as carpentry work and other casual work. The coefficient for participation is, again, not significant. It shows no evidence that the program affects other incomes. Regarding other factors, young farmers are more efficient in all models, probably because they can work physically harder.

The average technical efficiency estimates are 0.947 for participants and 0.809 for non-participants. The $t$-test for the difference between the two estimates is significant at the $1 \%$ level. Table 6 presents the proportional distribution of technical efficiencies for participants and non-participants. Several participants experience high technical efficiencies, while many non-participants experience low efficiencies. 
Additionally, Table 6 compares the distribution of estimated technical efficiencies between those participating and not participating in the program. This indicates that those participating in the program have higher ranges of incomes.

Table 3. Estimates of the stochastic function model for the total income.

\begin{tabular}{|c|c|c|}
\hline Variable & \multicolumn{2}{|c|}{ Estimates } \\
\hline \multicolumn{3}{|c|}{ Frontier model } \\
\hline constant & 9.807 & $* * *$ \\
\hline labor & -3.452 & $* * *$ \\
\hline farm & 0.485 & * \\
\hline forest & -0.356 & \\
\hline animal & 0.277 & \\
\hline labor^2 & 1.557 & * \\
\hline farm ^2 & 0.047 & \\
\hline forest ${ }^{\wedge}$ & -0.017 & \\
\hline animal`2 & -0.044 & $*$ \\
\hline labor*farm & 0.791 & * \\
\hline labor forest & -0.239 & \\
\hline labor animal & 0.303 & \\
\hline farm ${ }^{*}$ forest & -0.167 & $* * *$ \\
\hline farm ${ }^{*}$ animal & -0.260 & \\
\hline forest ${ }^{*}$ animal & 0.080 & \\
\hline \multicolumn{3}{|c|}{ Inefficiency model } \\
\hline$\delta 0$ & 0.238 & \\
\hline participation & -0.471 & $* * *$ \\
\hline age20_29 & 0.139 & \\
\hline age30above & 0.267 & * \\
\hline educ_0 & -0.055 & \\
\hline educ1_4 & -0.069 & \\
\hline educ5_9 & -0.200 & \\
\hline female & 0.022 & \\
\hline distance & -0.128 & $* * *$ \\
\hline village_A & 0.037 & \\
\hline village_E & -0.186 & \\
\hline$\sigma^{2}$ & 0.099 & $* * *$ \\
\hline$\gamma$ & 0.259 & $* * *$ \\
\hline$n$ & 120 & \\
\hline
\end{tabular}

Table 4. Estimates of the stochastic function model for agricultural income.

\begin{tabular}{|c|c|c|}
\hline Variable & \multicolumn{2}{|c|}{ Estimates } \\
\hline \multicolumn{3}{|c|}{ Frontier model } \\
\hline constant & 12.296 & $* * *$ \\
\hline labor & -5.847 & $* * *$ \\
\hline farm & 1.507 & $* *$ \\
\hline forest & -0.201 & \\
\hline animal & -0.604 & \\
\hline labor 2 & 1.350 & $*$ \\
\hline $\operatorname{farm}^{\wedge} 2$ & -0.180 & \\
\hline forest ${ }^{\wedge} 2$ & -0.021 & \\
\hline animal`2 & 0.010 & $*$ \\
\hline labor*farm & -0.336 & * \\
\hline labor ${ }^{*}$ forest & -0.074 & \\
\hline labor*animal & 0.905 & \\
\hline farm ${ }^{*}$ forest & -0.088 & \\
\hline farm ${ }^{*}$ animal & -0.320 & $*$ \\
\hline forest ${ }^{*}$ animal & 0.01207 & \\
\hline
\end{tabular}


Table 4. Cont.

\begin{tabular}{cc}
\hline Variable & Estimates \\
\hline & Inefficiency model \\
\hline s0 & 0.027 \\
participation & -0.015 \\
age20_29 & 0.479 \\
age30above & 0.601 \\
educ_0 & -0.723 \\
educ1_4 & 0.003 \\
educ5_9 & -0.176 \\
female & -0.496 \\
distance & -0.047 \\
village_A & -0.340 \\
village_E & -0.100 \\
$\sigma^{2}$ & 0.117 \\
$\gamma$ & 0.166 \\
$n$ & 120 \\
\hline Note: & $* * * *$ \\
\end{tabular}

Table 5. Estimates of the stochastic function model for other incomes.

\begin{tabular}{|c|c|c|}
\hline Variable & Estimate & \\
\hline \multicolumn{3}{|c|}{ Frontier model } \\
\hline constant & 8.310 & * \\
\hline labor & -10.099 & \\
\hline farm & -0.472 & \\
\hline forest & -1.178 & \\
\hline animal & 1.967 & $* *$ \\
\hline labor^2 & 3.997 & * \\
\hline $\operatorname{farm}^{\wedge} 2$ & 0.186 & \\
\hline forest $^{\wedge} 2$ & -0.040 & \\
\hline animal`2 & -0.279 & $* * *$ \\
\hline labor*farm & 0.924 & \\
\hline labor ${ }^{*}$ forest & -0.803 & * \\
\hline labor*animal & 0.577 & \\
\hline farm $^{*}$ forest & -0.316 & $* *$ \\
\hline farm*animal & -0.061 & \\
\hline forest ${ }^{*}$ animal & 0.35593 & $* *$ \\
\hline \multicolumn{3}{|c|}{ Inefficiency model } \\
\hline$\delta 0$ & -45.325 & \\
\hline participation & 0.780 & \\
\hline age20_29 & -2.354 & \\
\hline age30above & 11.058 & * \\
\hline educ_0 & 8.523 & \\
\hline educ1_4 & 9.713 & \\
\hline educ5_9 & 10.301 & * \\
\hline female & 7.673 & \\
\hline distance & -0.221 & \\
\hline village_A & 14.925 & \\
\hline village_E & 8.627 & \\
\hline$\sigma^{2}$ & 23.031 & $* * *$ \\
\hline$\gamma$ & 0.996 & $* * *$ \\
\hline$n$ & 120 & \\
\hline
\end{tabular}

Note: ${ }^{* * *} p<0.01,{ }^{* *} p<0.05,{ }^{*} p<0.1$ 
Table 6. Distribution of technical efficiencies of the total incomes.

\begin{tabular}{ccc}
\hline Range of Technical Efficiency & Participant (\%) & Non-Participant (\%) \\
\hline $0-0.7$ & 1.7 & 11.7 \\
$0.7-0.8$ & 11.7 & 13.3 \\
$0.8-0.9$ & 23.3 & 20.0 \\
$0.9-1.0$ & 63.3 & 55.0 \\
total & 100 & 100 \\
\hline
\end{tabular}

\section{Discussion}

This study has revealed that the program has a positive effect on the efficiency of the household economy. Prior studies have applied stochastic production function models to estimate the inefficiencies due to the excess capacity of agricultural production [63-65]. Previous studies have also demonstrated various factors of inefficiency in agricultural production. Additionally, this study has found that the communal land distribution program improves farm efficiency.

Jayne et al. [66] have shown that additional income sources other than conventional farming are needed in rural Ethiopia. Hitayezu et al. [67] argue that time allocation to rural non-farm activities increases with high labor availability and low productivity of farmland. Our study suggests that communal land distribution generates new sources of income in areas with abundant labor and less productive farmland.

A probable reason for the efficiency improvement of the program is that participants use excessive labor in program activities, such as tree planting. Since the labor force is more than what is necessary for production, disguised unemployment [40] exists in the rural areas of Ethiopia [68]. Engagement in program activities rarely results in the sacrifice of farming and other income.

It should be noted that this study's approach can only be applied to areas where social or natural conditions are like the study site. The area is a mountainous location with suitable climate conditions for tree planting. Therefore, the number of applicants for the program is higher than those of available plots. However, in multiple other areas where activities in communal lands are less profitable, the number of applicants is not sufficient [59].

\section{Conclusions}

Since there is a trade-off between farmers' incomes and land conservation in areas in the East African highlands, a temporal increase in farm incomes is likely to cause land degradation [69]. This study shows that the hillside distribution program in Ethiopia is an epoch-making policy that overcomes the trade-off and achieves both income generation and land conservation of hillside areas.

We estimate a stochastic production function model to evaluate the effect of the communal land distribution policy for tree planting on farm production efficiency and compare the technical efficiencies between both participating and nonparticipating farms in the program using a quasi-experimental method. The results reveal the improvement of efficiency through communal land distribution.

This finding poses the following implications to rural policies in many underdeveloped countries where there are limited non-farm employment opportunities and communal lands are not economically utilized. Since the labor for tree planting does not sacrifice labor for farming where non-farm employment opportunities are limited, a communal land distribution program will increase the efficiency of farm production and increase farm household incomes.

Several underdeveloped countries experience difficulties in increasing agricultural incomes due to the decline in farm area per capita. This is caused by a rapid population increase and the under-development of non-agricultural sectors. In these situations, the distribution of communal lands to poor farmers could increase their incomes. However, it should also be noted that many communal lands offer sources of animal fodder for local farmers, and, therefore, not all lands can be distributed. Additionally, communal lands are likely to offer eco-system services or various non-monetary benefits 
to people in local and downstream areas. We must carefully evaluate how communal land distribution may affect such non-economic values before program implementation.

Since this study used a relatively small sample, the evidence of this study is only applicable to a small area in Ethiopia. Nonetheless, this study proposes a new method of policy evaluation that is less expensive but equivalent to the randomized controlled trial (RCT), which is often criticized for its high financial and social costs of implementation, as well as its ethical issues [70]. The generality of this study's findings may be confirmed by conducting similar surveys and applying the same method in broader areas.

Author Contributions: Conceptualization, S.O., M.B., and K.T.; methodology, S.O.; investigation, M.B., K.T. and S.O.; data curation, S.O.; formal analysis, S.O.; writing-original draft preparation, S.O.; writing-review and editing, M.B., K.T., and S.O.; supervision, S.O.; project administration, K.T. All authors have read and agreed to the published version of the manuscript.

Funding: This research received no external funding.

Acknowledgments: This study results from the following research projects: The Establishment of Sustainable Rural Society with Low GHG Emission in the Tigray Region, Ethiopia, and the Forest and Farmland Conservation for Watershed Management in the Ethiopian Highlands Research Project of Japan International Research Center for Agricultural Sciences. The authors thank Gebremichael Negusse for useful suggestions for this study.

Conflicts of Interest: The authors declare no conflict of interest.

\section{References}

1. Oniki, S.; Negusse, G. Communal land utilization in the highlands of northern Ethiopia: Evidence of transaction costs. Jpn. J. Rural Econ. 2015, 17, 40-45.

2. Pender, J.; Gebremedhin, B. Determinants of agricultural and land management practices and impacts on crop production and household income in the highlands of Tigray, Ethiopia. J. Afr. Econ. 2007, 17, 395-450. [CrossRef]

3. Knudsen, M.H.; Fold, N. Land distribution and acquisition practices in Ghana's cocoa frontier: The impact of a state-regulated marketing system. Land Use Policy 2011, 28, 378-387. [CrossRef]

4. Rodríguez, L.G.; Pérez, M.R.; Yang, X.S.; Geriletu, G.; Belcher, B.; Zhou, B.Z.; Li, Z.C. Maintaining the contract responsibility system of forest land distribution in China: Evidence from a novel financial compensation scheme in Daxi Village of Anji County, Zhejiang. Land Use Policy 2013, 30, 863-872. [CrossRef]

5. Keswell, M.; Carter, M.R. Poverty and land redistribution. J. Dev. Econ. 2014, 110, $250-261$.

6. Rojas, E.; Meganck, R.A. Affecting Rural Displacement through Land Distribution Policies in the Eastern Caribbean. Urban. Law Policy 1988, 9, 53-67.

7. Bardhan, P.; Luca, M.; Mookherjee, D.; Pino, F. Evolution of land distribution in West Bengal 1967-2004: Role of land reform and demographic changes. J. Dev. Econ. 2014, 110, 171-190. [CrossRef]

8. Zhang, Y.Q. The impacts of economic reform on the efficiency of silviculture: A non-parametric approach. Environ. Dev. Econ. 2002, 7, 107-122. [CrossRef]

9. Liu, C.; Yin, R.S. Poverty dynamics revealed in production performance and forestry in improving livelihoods: The case of West Anhui, China. For. Policy Econ. 2004, 6, 391-401. [CrossRef]

10. Bonds, M.H.; Hughes, D.R. On the productivity of public forests: A stochastic frontier analysis of Mississippi school trust timber production. Can. J. Agric. Econ. Rev. Can. D Agroecon. 2007, 55, 171-183. [CrossRef]

11. Ofori-Bah, A.; Asafu-Adjaye, J. Scope economies and technical efficiency of cocoa agroforesty systems in Ghana. Ecol. Econ. 2011, 70, 1508-1518.

12. Frey, G.E.; Fassola, H.E.; Pachas, A.N.; Colcombet, L.; Lacorte, S.M.; Renkow, M.; Perez, O.; Cubbage, F.W. A Within-Farm Efficiency Comparison of Silvopasture Systems with Conventional Pasture and Forestry in Northeast Argentina. Land Econ. 2012, 88, 639-657.

13. De los Santos-Montero, L.A.; Bravo-Ureta, B.E. Natural Resource Management and Household Well-being: The Case of POSAF-II in Nicaragua. World Dev. 2017, 99, 42-59.

14. Kelly, V.; Diagana, B.; Reardon, T.; Gaye, M.; Crawford, E. Cash crop and foodgrain productivity in Senegal: Historical view, new survey evidence and policy implications. Msu Int. Dev. Pap. 1996, 20, 1-128.

15. Bryceson, D.F. Deagrarianization and rural employment in sub-Saharan Africa: A sectoral perspective. World Dev. 1996, 24, 97-111. 
16. Collier, P.; Dercon, S. African Agriculture in 50 Years: Smallholders in a Rapidly Changing World? World Dev. 2014, 63, 92-101. [CrossRef]

17. Barrett, C.B.; Reardon, T.; Webb, P. Nonfarm income diversification and household livelihood strategies in rural Africa: Concepts, dynamics, and policy implications. Food Policy 2001, 26, 315-331. [CrossRef]

18. Ellis, J.E.; Swift, D.M. Stability of African Pastoral Ecosystems-Alternate Paradigms and Implications for Development. J. Range Manag. 1988, 41, 450-459. [CrossRef]

19. Ricker-Gilbert, J.; Jumbe, C.; Chamberlin, J. How does population density influence agricultural intensification and productivity? Evidence from Malawi. Food Policy 2014, 48, 114-128. [CrossRef]

20. Pender, J.L. Population growth, agricultural intensification, induced innovation and natural resource sustainability: An application of neoclassical growth theory. Agric. Econ. 1998, 19, 99-112. [CrossRef]

21. Ehui, S.; Polson, R. A review of the economic and ecological constraints on animal draft cultivation in Sub-Saharan Africa. Soil Tillage Res. 1993, 27, 195-210. [CrossRef]

22. Alwang, J.; Siegel, P.B. Labor shortages on small landholdings in Malawi: Implications for policy reforms. World Dev. 1999, 27, 1461-1475. [CrossRef]

23. Leonardo, W.J.; van de Ven, G.W.J.; Udo, H.; Kanellopoulos, A.; Sitoe, A.; Giller, K.E. Labour not land constrains agricultural production and food self-sufficiency in maize-based smallholder farming systems in Mozambique. Food Secur. 2015, 7, 857-874. [CrossRef]

24. Tiffen, M. Transition in sub-Saharan Africa: Agriculture, urbanization and income growth. World Dev. 2003, 31, 1343-1366.

25. Place, F.; Ssenteza, J.; Otsuka, K. Customary and private land management in Uganda. In Land Tenure and Natural Resource Management: Comparative Study of Agrarian Communities in Asia and Africa; Otsuka, K., Place, F., Eds.; John Hopkins University Press: Baltimore, MD, USA, 2001; pp. 195-233.

26. Place, F.; Otsuka, K. Tenure, agricultural investment, and productivity in the customary tenure sector of Malawi. Econ. Dev. Cult. Chang. 2001, 50, 77-99. [CrossRef]

27. Sakurai, T.; Rayamajhi, S.; Pokharel, R.K.; Otsuka, K. Efficiency of timber production in community and private forestry in Nepal. Environ. Dev. Econ. 2004, 9, 539-561. [CrossRef]

28. Kabubo-Mariara, J. Land conservation and tenure security in Kenya: Boserup's hypothesis revisited. Ecol. Econ. 2007, 64, 25-35. [CrossRef]

29. Besley, T. Property-Rights and Investment Incentives-Theory and Evidence from Ghana. In Readings in Development Microeconomics; Bardhan, P.K., Udry, C., Eds.; The MIT Press: Cambridge, MA, USA, 1995; pp. 389-427.

30. Lanckriet, S.; Derudder, B.; Naudts, J.; Bauer, H.; Deckers, J.; Haile, M.; Nyssen, J. A Political Ecology Perspective of Land Degradation in the North Ethiopian Highlands. Land Degrad. Dev. 2015, 26, 521-530.

31. Hagos, F.; Pender, J.; Gebreselassie, N. Land Degradation in the Highlands of Tigray and Strategies for Sustainable Land Management; International Livestock Research Institute: Addis Ababa, Ethiopia, 1999.

32. Yami, M.; Mekuria, W.; Hauser, M. The effectiveness of village bylaws in sustainable management of community-managed exclosures in Northern Ethiopia. Sustain. Sci. 2013, 8, 73-86.

33. Holden, S.T.; Ghebru, H. Welfare impacts of land certification in Tigray, Ethiopia. In Land Tenure Reform in Asia and Africa: Assessing Impacts on Poverty and Natural Resource Management; Holden, S.T., Otsuka, K., Deininger, K., Eds.; Palgave Macmillan: London, UK, 2013; pp. 137-161.

34. Bezu, S.; Holden, S. Are Rural Youth in Ethiopia Abandoning Agriculture? World Dev. 2014, 64, $259-272$.

35. Holden, S.T.; Bekele, S.; Shiferaw, B.A.; Pender, J. Bioeconomic model with market imperfection. In Strategies for Sustainable Land Management in the East African Highlands; Pender, J., Place, F., Ehui, S., Eds.; International Food Policy Research Institute: Washington, DC, USA, 2006; Volume 140.

36. Jagger, P.; Pender, J.; Gebremedhin, B. Trading Off Environmental Sustainability for Empowerment and Income: Woodlot Devolution in Northern Ethiopia. World Dev. 2005, 33, 1491-1510. [CrossRef]

37. Bouriaud, L. Causes of illegal logging in Central and Eastern Europe. Small-Scale For. Econ. Manag. Policy 2005, 4, 269-291. [CrossRef]

38. Li, W.J.; Ali, S.H.; Zhang, Q. Property rights and grassland degradation: A study of the Xilingol Pasture, Inner Mongolia, China. J. Environ. Manag. 2007, 85, 461-470.

39. Lewis, W.A. Economic development with unlimited supplies of labour. Manch. Sch. 1954, 22, $139-191$. [CrossRef] 
40. Nurkse, R. Problems of Capital Formation in Underdeveloped Countries; Oxford University Press: Oxford, UK, 1959.

41. Babatunde, R.O.; Qaim, M. Impact of off-farm income on food security and nutrition in Nigeria. Food Policy 2010, 35, 303-311. [CrossRef]

42. Reardon, T. Using evidence of household income diversification to inform study of the rural nonfarm labor market in Africa. World Dev. 1997, 25, 735-747. [CrossRef]

43. Reardon, T.; Berdegue, J.; Barrett, C.; Stamoulis, K. Household Income Diversification into Rural Non-Farm Activities; Johns Hopkins University Press: Baltimore, MD, USA, 2006.

44. Otsuka, K.; Estudillo, J.P.; Sawada, Y. Toward a new paradigm of farm and nonfarm linkages in economic development. In Rural Poverty and Income Dynamics in Asia and Africa; Otsuka, K., Estudillo, J.P., Sawada, Y., Eds.; Routledge: New York, NY, USA, 2009; pp. 1-21.

45. Bhaumik, S.K.; Dimova, R.; Nugent, J.B. Off-farm labor supply and labor markets in rapidly changing circumstances: Bulgaria during transition. Econ. Syst. 2011, 35, 378-389. [CrossRef]

46. Scheidel, A.; Giampietro, M.; Ramos-Martin, J. Self-sufficiency or surplus: Conflicting local and national rural development goals in Cambodia. Land Use Policy 2013, 34, 342-352. [CrossRef]

47. Himanshu, H.; Lanjouw, P.; Murgai, R.; Stern, N. Nonfarm diversification, poverty, economic mobility, and income inequality: A case study in village India. Agric. Econ. 2013, 44,461-473. [CrossRef]

48. Nagler, P.; Naude, W. Non-farm enterprises in rural Africa: New empirical evidence. World Bank Policy Res. Work. Pap. 2014, 7066, 1-45.

49. Duguma, L.A. Financial analysis of agroforestry land uses and its implications for smallholder farmers livelihood improvement in Ethiopia. Agroforest Syst. 2013, 87, 217-231. [CrossRef]

50. Duguma, L.A.; Hager, H. Farmers' assessment of the social and ecological values of land uses in central highland Ethiopia. Environ. Manag. 2011, 47, 969-982. [CrossRef] [PubMed]

51. Paquette, A.; Hawryshyn, J.; Senikas, A.V.; Potvin, C. Enrichment Planting in Secondary Forests: A Promising Clean Development Mechanism to Increase Terrestrial Carbon Sinks. Ecol. Soc. 2009, 14, 15.

52. Alemu, Y.; Abibo, A.; Berhan, E. The Role of Nonfarm Activities on Income Generation to Rural Household; LAP Lambert: Saarbrucken, Germany, 2013.

53. Jones, A.; Breuning-Madsen, H.; Brossard, M.; Dampha, A.; Deckers, J.; Dewitte, O.; Gallali, T.; Hallett, S.; Jones, R.; Kilasara, M.; et al. Soil atlas of Africa; Publications Office of the European Union: Luxembourg, 2013.

54. Bekele, M. Forest Plantations and Woodlots in Ethiopia; African Forest Forum: Nairobi, Kenya, 2011.

55. Bekele-Tesemma, A. Useful Trees and Shrubs of Ethiopia: Identification, Propagation and Management for 17 Agroclimatic Zones; World Agroforestry Centre: Nairobi, Kenya, 2007.

56. Takenaka, K.; Abebe, B.; Tabuchi, R. Estimation of the stem volume of 30-year-old Eucalyptus globulus in the Northern Ethiopian Highlands. JARQ 2020, 54, 185-191. [CrossRef]

57. Central Statistical Agency. 2007 Population and Housing Census of Ethiopia; Central Statistical Agency: Addis Ababa, Ethiopia, 2007.

58. Berhe, M.; Hoag, D. The livelihood effects of landless people through communal hillside conservation in Tigray Region, Ethiopia. J. Dev. Agric. Econ. 2014, 6, 309-317.

59. Negash, T.; Oniki, S.; Berhe, M. Dependence level of rural landless households on allocated communal land: Evidences from Kilte awlaelo and Atsbi Wenberta Districts, Tigrai region, Northern Ethiopia. J. Land Rural. Stud. 2019, 8, 57-76.

60. Oniki, S.; Berhe, M.; Negash, T. Role of Social Norms in Natural Resource Management: The Case of the Communal Land Distribution Program in Northern Ethiopia. Land 2020, 9, 1-17.

61. Ahmed, M.M.; Gebremedhin, B.; Benin, S.; Ehui, S. Measurement and sources of technical efficiency of land tenure contracts in Ethiopia. Environ. Dev. Econ. 2002, 7, 507-527. [CrossRef]

62. Coelli, T.J. Recent developments in frontier modelling and efficiency measurement. Aust. J. Agric. Econ. 1995, 39, 219-245. [CrossRef]

63. Battese, G.E. Frontier production functions and technical efficiency: A survey of empirical applications in agricultural economics. Agric. Econ. 1992, 7, 185-208. [CrossRef]

64. Guan, Z.F.; Kumbhakar, S.C.; Myers, R.J.; Lansink, A.O. Measuring Excess Capital Capacity in Agricultural Production. Am. J. Agric. Econ. 2009, 91, 765-776. [CrossRef]

65. Timmer, C.P. Using a Probabilistic Frontier Production Function to Measure Technical Efficiency. J. Political Econ. 1971, 79, 776-794. 
66. Jayne, T.S.; Yamano, T.; Weber, M.T.; Tschirley, D.; Rui, B.F.; Chapoto, A.; Zulu, B. Smallholder income and land distribution in Africa: Implications for poverty reduction strategies. Food Policy 2003, 28, 253-275.

67. Hitayezu, P.; Okello, J.J.; Obel-Gor, C. Farm households' participation in rural non-farm employment in post-war Rwanda: Drivers and policy implications. Dev. S. Afr. 2014, 31, 452-474.

68. Denu, B.; Abraham, T.; van der Deijl, H. Characteristics and Determinants of Youth Unemployment, Underemployment and Inadequate Employment in Ethiopia; Employment Strategy Department, ILO: Genève, Switzerland, 2005.

69. Pender, J.; Nkonya, E.; Jagger, P.; Sserunkuuma, D.; Ssali, H. Strategies to increase agricultural productivity and reduce land degradation: Evidence from Uganda. Agric. Econ. 2004, 31, 181-195. [CrossRef]

70. Resnik, D.B. Randomized controlled trials in environmental health research: Ethical issues. J. Environ. Health 2008, 70, 28-30.

(C) 2020 by the authors. Licensee MDPI, Basel, Switzerland. This article is an open access article distributed under the terms and conditions of the Creative Commons Attribution (CC BY) license (http://creativecommons.org/licenses/by/4.0/). 